\title{
TINJAUAN TEORITIS DAN YURIDIS LEMBAGA PENJAMIN SIMPANAN
}

\author{
Ramadhani Irma. T \\ Fakultas Syari'ah dan Hukum UIN Sunan Gunung Djati Bandung \\ Jl. A. H. Nasution Nomor 105 Bandung \\ Email: irmakrishna@gmail.com
}

\begin{abstract}
Abstrak
Untuk menciptakan rasa aman dan kepercayaan nasabah penyimpan (deposan) serta menjaga stabilitas sistem perbankan dan perekonomian, dibentuk suatu Lembaga Penjamin Simpanan (LPS) sebagai pelaksana penjaminan dana masyarakat, tertera pada UURI Nomor 10 Tahun 1998 tentang Perbankan. Pada tanggal 22 September 2004, Presiden Republik Indonesia mengesahkan Undang-Undang Nomor 24 tahun 2004 tentang LPS. Berdasarkan undang-undang tersebut, LPS adalah suatu lembaga independen yang berfungsi menjamin simpanan nasabah penyimpan dan turut aktif dalam memelihara stabilitas sistem perbankan sesuai dengan kewenangannya. Undang-undang ini berlaku efektif sejak tanggal 22 September 2005, dan sejak tanggal tersebut LPS resmi beroperasi.
\end{abstract}

\section{Kata Kunci}

Kepercayaan, LPS, Rasa Aman, Stabilitas Perbankan

\section{A. Pendahuluan}

Pada tahun 1997, di Indonesia terjadi krisis ekonomi yang diawali oleh krisis nilai tukar rupiah terhadap dollar AS. Indonesia merupakan salah satu negara di Asia yang mengalami krisis mata uang, kemudian disusul oleh krisis moneter dan perbankan pada tahun 1998, paska dilikuidasinya 16 bank pada 1 November 1997. Setelah penetapan likuidasi 16 bank terjadi rush $^{1}$ kemudian diikuti dengan pelarian dan peralihan simpanan secara sistemik, yang pada akhirnya berlanjut dengan krisis ekonomi yang besar.

Pada saat itu pemerintah tidak siap menangani krisis perbankan hingga akhirnya harus membebani APBN yakni lebih dari Rp 600 triliun, untuk tindakan pengambilalihan beberapa bank-bank bermasalah agar sistem pembayaran tidak bangkrut. Saat itu perkiraan kondisi APBN 1999/2000 defisit sekitar 4,5\% dari Pendapatan Domestik Bruto (PDB), pada akhirnya menjadi beban yang cukup berat.

\footnotetext{
${ }^{1}$ Penarikan dana dalam jumlah yang besar secara bersamaan.
} 
Peristiwa tersebut berdampak melemahnya tingkat kepercayaan masyarakat pada sistem perbankan. Ini membuat pemerintah Indonesia tidak mempunyai pilihan selain mengeluarkan beberapa kebijakan, di antaranya memberikan jaminan atas seluruh kewajiban pembayaran bank, termasuk simpanan masyarakat pada bank (blanket guarantee) untuk mengatasi krisis yang terjadi. Blanket guarantee merupakan program pemberian jaminan terhadap kewajiban pembayaran bank umum kepada para pemilik dana baik deposan maupun kreditur sebagai salah satu upaya untuk membangun kembali sektor perbankan.

Secara umum pengertian blanket guarantee di dunia internasional adalah suatu instrumen tindakan darurat berupa pemberian jaminan pembayaran atas kewajiban bank-bank bermasalah baik terhadap para deposan maupun krediturnya. Pemberlakuan instrumen ini biasanya untuk sementara hingga krisis sistemik perbankan pulih dan beban anggaran akan ditanggung oleh pemerintah melalui otoritas pengawas atau lembaga yang khusus dibentuk atau ditunjuk untuk melaksanakan penyehatan dan restrukturisasi sistem perbankan dapat dikurangi atau diakhiri.

Dalam pelaksanaannya, blanket guarantee dapat menumbuhkan kembali kepercayaan masyarakat terhadap industri perbankan. Namun ruang lingkup penjaminan yang terlalu luas menyebabkan timbulnya moral hazard ${ }^{2}$ baik dari sisi pengelola bank maupun masyarakat, yakni mendorong meningkatnya Bantuan Liquiditas Bank Indonesia (BLBI) sehingga menempatkan Bank Indonesia (BI) pada situasi yang dilematis. Di satu sisi, peningkatan BLBI ditujukan dalam rangka menyelamatkan sistem perbankan sekaligus sistem pembayaran dan mencegah keterpurukan perekonomian nasional. Di sisi lain, peningkatan BLBI dapat menyebabkan masalah moneter yakni meningkatnya jumlah uang beredar. Peningkatan tersebut akan berdampak pada upaya pengendalian moneter guna meredam laju inflasi, menstabilkan nilai tukar rupiah, dan menstabilkan tingkat suku bunga. ${ }^{3}$

Untuk mengatasi hal tersebut dan agar tetap menciptakan rasa aman dan kepercayaan nasabah penyimpan (deposan) serta menjaga stabilitas sistem perbankan dan perekonomian, program penjaminan yang sangat luas lingkupnya tersebut perlu digantikan dengan sistem penjaminan yang terbatas. Jaminan tersebut tertera pada UU Nomor 10 Tahun 1998 tentang Perbankan yang mengamanatkan pembentukan suatu Lembaga Penjamin Simpanan (LPS) sebagai pelaksana penjaminan dana masyarakat.

2 Tindakan pelaku ekonomi yang menimbulkan kemudharatan baik untuk diri sendiri maupun orang lain; kecerobohan atau ketidakpedulian terhadap kerugian

3 Kusumaningtuti S. S., Ketentuan Blanket Guarantee dan Kemungkinan Penggantiannya dengan Deposit Protection Scheme. (Jakarta: BEMP. 1998), hal. 159. 
Pada tanggal 22 September 2004, Presiden Republik Indonesia mengesahkan UU Nomor 24 tahun 2004 tentang LPS. Berdasarkan Undang-Undang tersebut, LPS adalah suatu lembaga independen yang berfungsi menjamin simpanan nasabah penyimpan dan turut aktif dalam memelihara stabilitas sistem perbankan sesuai dengan kewenangannya. Undang-undang ini berlaku efektif sejak tanggal 22 September 2005, dan sejak tanggal tersebut LPS resmi beroperasi.

\section{B. Deposit Protection Scheme (DPS) sebagai Sarana Pendukung Stabilitas Perbankan}

Menurut Kusumaningtuti, pentingnya peranan bank dalam perekonomian dan sistem perbankan yang rapuh terhadap risiko yang sistemik adalah merupakan pembenaran terhadap perlindungan deposan melalui skim yang tepat dan memadai. Secara teoritis sistem perbankan yang tidak diregulasi dapat berfungsi tanpa skim perlindungan simpanan dan dapat beroperasi sehat melalui disiplin pasar. Tetapi di era kekinian yang semakin kompleks variabelnya, lebih-lebih di negara berkembang tak ada negara dengan sistem perbankan tanpa regulasi. Dalam era globalisasi ini, bank semakin dihadapkan pada beberapa karakteristik dengan berbagai jenis yang secara keseluruhan meningkatkan kemungkinan timbulnya contagious financial disorders. ${ }^{4}$ Oleh karena itu, sebagian besar sistem perbankan di dunia menerapkan jaring pengaman atau mekanisme perlindungan yang luas mencakup asuransi deposito, akses pada bantuan likuiditas pemerintah bahkan skim rekapitalisasi atau nasionalisasi yang didisain dalam rangka memperbaiki bank bermasalah dan mengamankan deposan apabila bank tersebut bangkrut (gagal bayar). Keberadaan jaring pengaman tersebut membuat bank-bank tidak lagi beroperasi berdasarkan pada disiplin pasar. Guna mencegah risiko tidak dialihkan ke dana asuransi simpanan atau ke lender of last resort (LOLR) ${ }^{5}$, maka pengawasan perbankan yang ketat dan tertib wajib lebih ditingkatkan.

Banyak negara-negara tanpa mekanisme asuransi implisit, ternyata telah menyelamatkan deposan-deposannya dari kegagalan bank. Namun, di sisi lain bila tidak terdapat sistem perlindungan nasabah yang direncanakan dengan baik, maka akan timbul ketidakpastian bagi deposan, dan potensi terjadinya pelarian simpanan keluar dari sistem perbankan menjadi lebih besar. Sebagai alternatif, perlindungan ekplisit lebih jelas batasan penjaminannya. Karena alasan inilah, maka banyak

${ }^{4}$ Ibid., hal. 161; contagious financial disorders adalah pengaruh buruk kekacauan keuangan.

${ }^{5}$ Pemberian fasilitas pinjaman kepada bank yang mengalami kesulitan likuiditas dan berfungsi untuk menghindarkan krisis keuangan yang sistemik. 
negara yang dewasa ini memilih untuk memiliki skim perlindungan simpanan yang eksplisit.

Perlindungan simpanan menjadi penting bagi yang bersentuhan dengan perbankan. Namun menetapkan sasaran suatu perlindungan simpanan merupakan hal yang perlu menjadi perhatian, gunanya untuk mengetahui dengan jelas target yang dituju dan menghindari keinginan semua pihak terkait untuk dimasukkan dalam skim perlindungan. Sasaran skim perlindungan asuransi umumnya diutamakan untuk melindungi dana deposan kecil dan dalam rangka menjamin/menyangga stabilitas sistem keuangan saat terjadi kegagalan bank.

\section{Persyaratan Pendirian DPS untuk Bentuk yang Efektif}

Deposit Protection Scheme (DPS) yang didisain dengan baik termasuk memperhatikan insentif yang diperlukan sesuai sasaran yang dituju, dapat mendorong pihak yang terkait dalam sistem perbankan untuk bertindak rasional, sehingga dapat mendukung sehatnya perekonomian nasional. 6

Secara teoritis perlindungan seperti itu, akan terlebih dahulu memperhitungkan insentif yang mendorong berfungsinya operasional perbankan secara disiplin. Artinya, keberadaan DPS akan membatasi campur tangan manajemen bank, memberikan insentif bagi deposan besar untuk mencari bank yang sehat, dan mendorong terciptanya ketentuan formal yang bertujuan mengamankan sistem perbankan. Apabila perhatian terhadap kekuatan pasar dilakukan secara seimbang, dan pengendalian pasar yang berlebih-lebihan dapat dihindarkan, maka DPS dapat mendorong terciptanya pasar keuangan yang efisien.

Disain deposit protection atau insurance scheme yang mendukung berfungsinya pasar (market friendly incentives), perlu mencakup hal-hal seperti:

a. diformulasikan secara eksplisit dalam undang-undang;

b. diwajibkan bagi semua anggota sistem perbankan (compulsary);

c. dilengkapi dengan prosedur akunting, penilaian kredit (loan valuation), perangkat peraturan dan mekanisme supervisi yang didisain baik;

d. lembaga perlindungan atau asuransi simpanan diberi kewenangan dan akses informasi yang diperlukan guna memperbaiki bank yang goyah serta diberi kewenangan untuk menangani secara efektif bank-bank yang insolven;

e. lembaga perlindungan atau asuransi simpanan tersebut dibentuk hanya setelah bank-bank yang tidak sehat telah direstrukturisasi; 
Ramadhani Irma T.: Tinjauan Teoritis dan Yuridis Lembaga Penjamin Simpanan | 237

f. tidak melakukan perbedaan perlakuan baik antara bank-bank besar dan kecil, maupun antara bank milik swasta dan milik pemerintah;

g. bercirikan cakupan yang terbatas untuk seluruh jenis simpanan;

h. tersedia penggantian segera bila terdapat bank yang gagal.

\section{Pengertian, Fungsi, Wewenang dan Tugas LPS}

Untuk mengatasi krisis yang terjadi seperti yang telah di uraiakan di atas. Pemerintah mengeluarkan beberapa kebijakan diantaranya memberikan jaminan atas seluruh kewajiban pembayaran bank, termasuk simpanan masyarakat (blanket guarantee). Hal ini ditetapkan dalam Keputusan Presiden Nomor 26 Tahun 1998 tentang Jaminan Terhadap Kewajiban Pembayaran Bank Umum dan Keputusan Presiden Nomor 193 Tahun 1998 tentang Jaminan Terhadap Kewajiban Pembayaran Bank Perkreditan Rakyat. Namun ruang lingkup penjaminan yang terlalu luas menyebabkan timbulnya moral hazard, maka untuk mengatasi hal tersebut dan agar tetap menciptakan rasa aman bagi nasabah penyimpan serta menjaga stabilitas sistem perbankan, program penjaminan yang sangat luas lingkupnya tersebut perlu digantikan dengan sistem penjaminan yang terbatas. Jaminan tersebut tertera pada UU Nomor 10 Tahun 1998 tentang Perbankan, pada Pasal 37 B yang merupakan Perubahan UU No. 7 Tahun 1992 mengamanatkan pembentukan suatu Lembaga Penjamin Simpanan (LPS) sebagai pelaksana penjaminan dana masyarakat.

Pada tanggal 22 September 2004, Presiden Republik Indonesia mengesahkan UU Nomor 24 tahun 2004 tentang LPS. LPS adalah suatu lembaga independen yang berfungsi menjamin simpanan nasabah perbankan di Indonesia. Undang-undang ini mulai berlaku efektif 12 bulan sejak diundangkan sehingga pendirian dan operasional LPS dimulai pada 22 September 2005. Setiap bank yang melakukan kegiatan usaha di wilayah Republik Indonesia wajib menjadi peserta penjaminan LPS.

LPS adalah perwujudan dari DPS menggunakan skim perlindungan simpanan yang eksplisit. Pentingnya keberadaan LPS, guna mencegah kepanikan nasabah dengan jalan menyakinkan nasabah tentang keamanan simpanan walaupun kondisi keuangan bank memburuk dan ancaman terjadinya risiko sistemik. Resiko ini terjadi karena kebangkrutan satu bank dapat berakibat buruk terhadap bank lain, sehingga menghancurkan segmen terbesar dari sistem perbankan.

Menurut UU Nomor 24 tahun 2004 tentang LPS, fungsi LPS ada dua, yaitu: menjamin simpanan nasabah penyimpan dan turut aktif dalam 
memelihara stabilitas sistem perbankan sesuai dengan kewenangannya. ${ }^{7}$ Adapun tugasnya dalam fungsi menjamin simpanan nasabah penyimpan adalah merumuskan dan menetapkan kebijakan pelaksanaan penjaminan simpanan; dan melaksanakan penjaminan simpanan. Sementara dalam fungsinya untuk turut aktif dalam memelihara stabilitas sistem perbankan sesuai dengan kewenangannya adalah merumuskan dan menetapkan kebijakan dalam rangka turut aktif memelihara stabilitas sistem perbankan; merumuskan, menetapkan, dan melaksanakan kebijakan penyelesaian bank gagal (bank resolution) yang tidak berdampak sistemik; dan melaksanakan penanganan bank gagal yang berdampak sistemik. ${ }^{8}$

Wewenang LPS menurut pasal Pasal 6 UU Nomor 24 tahun 2004 tentang LPS adalah sebagai berikut:

a. Menetapkan dan memungut premi penjaminan.

b. Menetapkan dan memungut kontribusi pada saat bank pertama kali menjadi peserta.

c. Melakukan pengelolaan kekayaan dan kewajiban LPS.

d. Mendapatkan data simpanan nasabah, data kesehatan bank, laporan keuangan bank, dan laporan hasil pemeriksaan bank sepanjang tidak melanggar kerahasiaan bank.

e. Melakukan rekonsiliasi, verifikasi, dan/atau konfirmasi atas data tersebut pada angka 4.

f. Menetapkan syarat, tata cara, dan ketentuan pembayaran klaim.

g. Menunjuk, menguasakan, dan/atau menugaskan pihak lain untuk bertindak bagi kepentingan dan/atau atas nama LPS, guna melaksanakan sebagian tugas tertentu.

h. Melakukan penyuluhan kepada bank dan masyarakat tentang penjaminan simpanan.

i. Menjatuhkan sanksi administratif.

Pihak yang hendak dilindungi oleh LPS adalah (1) para pemilik uang pada bank, (2) badan usaha bank beserta sumber daya manusia yang bekerja padanya, dan (3) aktivitas usaha perbankan bank yang bersangkutan yang perlu dilindungi agar tetap sehat dan stabil dalam rangka menunjang terwujudnya perekonomian nasional yang stabil dan tangguh. Dengan demikian, jika dilihat dari segi fungsi dan kewenangannya, dapat dikatakan LPS tidak lain merupakan alat perlengkapan negara/pemerintah untuk menjalankan fungsi-fungsi kekuasaan negara di bidang-bidang tersebut di atas. ${ }^{9}$

\footnotetext{
${ }^{7}$ Pasal 4 UU Nomor 24 tahun 2004 tentang LPS

8 Pasal 5 UU Nomor 24 tahun 2004 tentang LPS

9 UU Nomor 24 tahun 2004 tentang LPS Bab III fungsi, tugas dan wewenang LPS
} 
Karena sifat pekerjaannya, maka sistem pengelolaan keuangan diperlukan mekanisme yang terpisah dari mekanisme APBN. Karena itulah, status kelembagaannya ditetapkan sebagai suatu bentuk badan hukum dengan kekayaan yang terpisah dari keuangan negara yang lazimnya terkait dengan pengertian Anggaran Pendapatan dan Belanja Negara (APBN). Dengan adanya mekanisme tersendiri demikian, LPS dapat bertindak melakukan transaksi dalam bidang hukum privat seperti halnya suatu badan hukum yang bergerak dalam bidang hukum bisnis. Seluruh biaya penanganan bank gagal yang dikeluarkan oleh LPS menjadi penyertaan modal sementara LPS pada bank yang bersangkutan.

\section{Peran LPS sebagai Jaring Pengaman Sistem Perbankan Nasional}

Sebelum menjelaskan peran LPS dalam menjamin simpanan nasabah dan memelihara stabilitas sistem perbankan dikemukakan terlebih dahulu hubungan kelembagaan atau koordinasi dengan Otoritas Jasa Keuangan $(\mathrm{OJK})$, BI, LPS, Kementerian Keuangan, dan Forum Koordinasi Stabilitas Sistem Keuangan (FKSSK).

Menurut paparan beberapa pakar, untuk pengamanan sistem perbankan nasional penerapannya dapat dianalogikan sebagai tim sepak bola ada penyerang, pemain tengah, bek (pemain belakang) dan kiper. Setiap posisi punya peran masing-masing. Jika dianalogikan dengan sistem perbankan kita memiliki fungsi masing-masing. OJK berperan sebagai ujung tombak (front office). Dengan perannya mengatur dan mengawasi mikroprudensial dengan kuat dan efektif. OJK diharapkan mampu mendorong perbankan untuk mencapai tujuan, yaitu sistem perbankan yang sehat, stabil, bertumbuh, dan bermanfaat bagi rakyat banyak. Selain itu, dengan mengidentifikasi permasalahan secara dini dan prompt corrective actions diharapkan permasalahan perbankan dapat diatasi pada stadium awal.

Adapun tujuan OJK dibentuk agar keseluruhan kegiatan di dalam sektor jasa keuangan:

a. terselenggara secara teratur, adil, transparan, dan akuntabel;

b. mampu mewujudkan sistem keuangan yang tumbuh secara berkelanjutan dan stabil; dan

c. mampu melindungi kepentingan konsumen dan masyarakat.

Berdasarkan Pasal 41 UU No. 21 Tahun 2011 tentang 0JK, bahwa OJK menginformasikan kepada LPS mengenai bank bermasalah yang 
sedang dalam upaya penyehatan oleh OJK sebagaimana dimaksud dalam peraturan perundang-undangan.

Selanjutnya di belakang OJK berdiri BI sebagai lini tengah berperan mengatur kebijakan makroprudensial (moneter dan sistem pembayaran) yang kondusif bagi industri perbankan sehingga dapat membantu menciptakan peluang terjadinya goal. Peran konkrit BI, saat sebuah bank menghadapi masalah likuiditas, BI bisa memberikan fasilitas pinjaman likuiditas sebagai bentuk pertahanan terhadap sistem ekonomi Indonesia.

LPS berada pada posisi belakang/bertahan, LPS melakukan penyelamatan, dalam arti menjamin simpanan nasabah bank yang dicabut izinnya dan melaksanakan resolusi (penyehatan) bank gagal. Bank gagal dan bank yang dicabut izinnya pada umumnya mengalami permasalahan solvabilitas. Pelaksanaan fungsi tersebut dimaksudkan untuk memberikan perlindungan, rasa aman, dan ketenangan sehingga dapat meningkatkan kepercayaan masyarakat terhadap perbankan. Sekalipun diperbolehkan melakukan penyelamatan, bukan berarti dana talangan dari LPS akan hilang. Semua biaya yang timbul akibat melakukan penyelamatan suatu bank akan diperhitungkan sebagai penyertaan sementara. Jangka waktu penyertaan LPS dibatasi dan harus menjual kembali sahamnya maksimal 2-3 tahun sejak penyelamatan dilakukan.

Di samping itu, berdasarkan UU No. 21 Tahun 2011 OJK, LPS dapat melakukan pemeriksaan terhadap bank yang terkait dengan fungsi, tugas dan wewenangnya serta berkoordinasi terlebih dahulu dengan 0JK, karena pada dasarnya wewenang pemeriksaan terhadap bank adalah wewenang 0JK. Berdasarkan undang-undang, lingkup pemeriksaan LPS terhadap bank meliputi pemeriksaan premi, posisi simpanan, tingkat bunga, kredit macet dan tercatat, bank bermasalah, kualitas aset, dan kejahatan di sektor perbankan. ${ }^{10}$ Selanjutnya BI dan LPS wajib membangun dan memelihara sarana pertukaran informasi secara terintegrasi. 11

Jika ketiga pertahanan tersebut tidak mampu bertahan juga, Kementerian Keuangan adalah pemain terakhir yang diharapkan mampu menjaga gawang tetap aman. Kemenkeu sebagai pemegang otoritas terhadap fiskal dan koordinator jaminan pengaman keuangan, 
Financial Safety Nets (FSN), mampu memberikan kebijakan untuk menjaga sistem perbankan tetap stabil. Untuk menjaga stabilitas sistem keuangan dibentuklah FKSSK. ${ }^{12}$

Berkenaan dengan pengambilan keputusan dalam kondisi kesulitan keuangan yang berdampak sistemik dan mengantipasi ancaman krisis keuangan global yang dapat membahayakan stabilitas sistem keuangan dan perekonomian nasional, maka pemerintah membuat suatu landasan hukum yang kuat, mekanisme koordinasi antar lembaga, serta mekanisme pengambilan keputusan yang efektif dan tepat sehingga tindakan pencegahan dan penanganan krisis dapat dilakukan secara terpadu, efisien, dan efektif. ${ }^{13}$

\section{Peran LPS dalam Melakukan Penanganan Bank Gagal yang Berdampak Sistemik dengan Penyertaan Modal oleh Peme- gang Saham.}

Bank gagal berdampak sistemik adalah apabila kegagalan bank akan berdampak luar biasa baik dalam rush maupun terhadap kelancaran dan kelangsungan roda perekonomian secara nasional. Untuk penanganan bank gagal dengan skim apapun, pihak LPS berdasarkan UU No. 24 Tahun 2004 tentang LPS, diberikan kewenangan yang sangat memadai. Kewenangan Rapat Umum Pemegang Saham (RUPS) dan pengelolaan bank gagal sepenuhnya diserahkan kepada LPS sehingga program penyelamatan dapat dilakukan lebih efektif. Termasuk dalam kewenangan yang diberikan kepada LPS adalah untuk melakukan penyertaan sementara, melakukan merger dan konsolidasi dengan bank lain.

Dalam menangani bank gagal yang sistemik maupun tidak pihak LPS akan melakukan kajian dan memutuskan akan diselamatkan atau tidak. Jika biaya penyelamatan jauh lebih mahal dari pada dengan likuidasi, maka penyelesaiannya singkat saja. Bank diusulkan dicabut ijin usahanya, kemudian dilikuidasi dan LPS membayar klaim atas simpanan masyarakat. Apabila LPS memutuskan untuk melakukan penyelamatan, maka ada perbedaan perlakuan antara ke duanya.

LPS adalah bagian dari sistem Jaring Pengaman Sektor Keuangan (JPSK)/anggota FKSSK bersama dengan BI, Menteri Keuangan, dan OJK.

\footnotetext{
12 Samman Abu Lubis, "Memahami Peran Lembaga Penjamin Simpanan sebagai Jaring Pengaman Sistem Perbankan Nasional". Makalah (2014), hal. 3.

13 Pasal 11 ayat ( 5 ) UU No 3 Tahun 2004 tentang BI
} 
FKSSK menetapkan dan melaksanakan kebijakan yang diperlukan dalam rangka pencegahan dan penanganan krisis pada sistem keuangan sesuai dengan kewenangan masing-masing. Keputusan FKSSK yang terkait dengan penyelesaian dan penanganan suatu bank gagal (bank resolotion) yang ditangani berdampak sistemik mengikat LPS.

LPS menangani bank gagal yang berdampak sistemik ditetapkan di dalam Pasal 22 dan Pasal 23 (1), 25, 26, 27 dan 28 UU LPS. LPS melakukan penanganan bank gagal yang berdampak sistemik setelah FKSSK menyerahkan penanganannya kepada LPS. Penyelesaian atau penanganan bank gagal berdampak sistemik dengan cara: melakukan penyelamatan yang mengikutsertakan pemegang saham lama atau tanpa mengikutsertakan pemegang saham lama. Penanganan bank gagal yang berdampak sistemik dengan mengikutsertakan pemegang saham lama (open bank assistance) hanya dapat dilakukan apabila:

a. pemegang saham bank gagal telah menyetor modal sekurangkurangnya $20 \%$ dari perkiraan biaya penanganan;

b. ada pernyataan dari RUPS yang sekurang-kurangnya memuat kesediaan untuk:

1) menyerahkan kepada LPS hak dan wewenang RUPS;

2) menyerahkan kepada LPS kepengurusan bank;

3) dan tidak menuntut LPS atau pihak yang ditunjuk LPS dalam hal proses penanganan tidak berhasil, sepanjang LPS atau pihak yang ditunjuk LPS melakukan tugasnya sesuai dengan peraturan perundang-undangan.

c. bank menyerahkan kepada LPS dokumen mengenai:

1) penggunaan fasilitas pendanaan dari Bank Indonesia;

2) data keuangan Nasabah Debitur;

3) struktur permodalan dan susunan pemegang saham tiga tahun terakhir; dan

4) informasi lainnya yang terkait dengan aset, kewajiban dan permodalan bank yang dibutuhkan LPS.

Terhitung sejak LPS menetapkan untuk melakukan penanganan bank gagal yang berdampak sistemik dengan penyertaan modal dengan pemegang saham, berdasarkan UU No. 24 Tahun 2004 tentang LPS:

a. pemegang saham dan pengurus bank melepaskan dan menyerahkan kepada LPS segala hak, kepemilikan, kepengurusan dan/atau kepentingan lain pada bank dimaksud; dan 
b. pemegang saham dan pengurus bank tidak dapat menuntut LPS dalam hal proses penanganan tidak berhasil, sepanjang LPS atau pihak yang ditunjuk LPS melakukan tugasnya sesuai dengan peraturan perundang-undangan.

LPS bertanggung jawab atas kekurangan biaya penanganan bank gagal setelah pemegang saham lama melakukan penyetoran modal sekurang-kurangnya $20 \%$ dari perkiraan biaya penanganan. Biaya penanganan bank gagal yang dikeluarkan oleh LPS menjadi penyertaan modal sementara LPS pada bank.

LPS wajib menjual seluruh saham bank dalam penanganan paling lama 3 (tiga) tahun sejak penyerahan segala hak, kepemilikan, kepengurusan dan/atau kepentingan lain pada bank dimaksud. Penjualan saham dilakukan secara terbuka dan transparan dengan tetap mempertimbangkan tingkat pengembalian yang optimal bagi LPS, paling sedikit sebesar seluruh penempatan modal sementara yang dikeluarkan oleh LPS. Dalam hal tingkat pengembalian yang optimal tidak dapat diwujudkan dalam jangka waktu paling lama 3 (tiga) tahun maka dapat diperpanjang sebanyak-banyaknya dua kali dengan masing-masing perpanjangan selama satu tahun.

Selanjutnya dalam hal tingkat pengembalian yang optimal yaitu 3 (tiga) tahun dan paling sedikit tingkat pengembalian sebesar seluruh penempatan modal sementara yang dikeluarkan oleh LPS tidak dapat diwujudkan dalam jangka waktu perpanjangan 2 (dua) kali dengan masing-masing perpanjangan selama 1 (satu) tahun, LPS menjual saham bank tanpa memperhatikan ketentuan tingkat pengembalian yang optimal, tanpa memperhatikan modal sementara yang dikeluarkan oleh LPS dalam jangka waktu satu tahun berikutnya.

Selanjutnya LPS dalam melakukan penyelesaian dan penanganan bank gagal mempunyai kewenangan diantaranya menguasai dan mengelola aset dan kewajiban bank gagal yang diselamatkan. Kemudian LPS menjamin simpanan nasabah bank yang berbentuk giro, deposito, sertifikat deposito, tabungan dan/atau bentuk lainnya yang dipersamakan dengan itu. Nilai simpanan yang dijamin untuk setiap nasabah pada satu bank paling banyak Rp 2.000.000.000,00 (dua milyar rupiah). Nilai yang dijamin diharapkan dapat melindungi seluruh simpanan yang dimiliki oleh nasabah kecil yang merupakan sebagian besar nasabah bank di Indonesia.

Namun demikian, berdasarkan Perpu No. 3 Tahun 2008 tentang Perubahan Atas UU No. 24 Tahun 2004 tentang LPS bahwa Nilai Simpanan yang dijamin dapat diubah apabila dipenuhi salah satu atau lebih kriteria sebagai berikut:

a. terjadi penarikan dana perbankan dalam jumlah besar secara bersamaan; 
b. terjadi inflasi yang cukup besar dalam beberapa tahun;

c. jumlah nasabah yang dijamin seluruh simpanannya menjadi kuran dari 90\% dari jumlah nasabah penyimpan seluruh bank; atau

d. terjadi ancaman krisis yang berpotensi mengakibatkan merosotnya kepercayaan masyarakat terhadap perbankan dan membahayakan stabilitas sistem keuangan.

Selanjutnya, kemungkinan bisa saja terjadi bahwa klaim penjaminan dinyatakan tidak layak dibayar apabila berdasarkan hasil rekonsiliasi dan/atau verifikasi terjadi:

a. data Simpanan nasabah dimaksud tidak tercatat di bank;

b. nasabah Penyimpan merupakan pihak yang diuntungkan secara tidak wajar; misalnya nasabah yang memperoleh hasil bunga jauh di atas tingkat pasar; dan

c. nasabah Penyimpan merupakan pihak yang menyebabkan keadaan bank menjadi tidak sehat, misalnya penerima kredit yang kreditnya macet. ${ }^{14}$

\section{E. Penyelamatan Bank Gagal yang Tidak Berdampak Sistemik}

Bank gagal yang tidak berdampak sistemik adalah ketidakmampuan bank dalam memenuhi kewajibannya kepada para deposannya atau karena tidak bisa membayar atau pemenuhan permintaan danadana lainnya yang masih merupakan bagian dari kewajibannya dan kegagalan bank tersebut tidak berdampak sistemik terhadap perekonomian nasional. Bank gagal bisa terjadi karena: manajemennya kacau dan tidak bisa mengurusnya, pemiliknya melarikan asetnya ke luar negeri untuk mengeruk keuntungan dari tabungan nasabahnya, atau terjadi krisis ekonomi. Untuk bank gagal tidak sistemik penyelamatan tidak mengikutsertakan pemegang saham lama, artinya segala biaya yang timbul untuk penyelamatan akan disediakan oleh pihak LPS.

Penyelamatan bank gagal yang tidak berdampak sistemik ditetapkan di dalam Peraturan Lembaga Penjamin Simpanan (LPS) Nomor 3/PLPS/2011 tentang Perubahan Kedua Atas Peraturan Lembaga Penjamin Simpanan Nomor 4/PLPS/2006 Tentang Penyelesaian bank gagal yang Tidak Berdampak Sistemik. Perubahan yang ditetapkan di antaranya Pasal 6 ayat (1) tentang Pemenuhan tingkat solvabilitas, memenuhi ketentuan rasio Kewajiban Penyediaan Modal Minimum

${ }_{14}$ Perpu No. 3 Tahun 2008 tentang Perubahan Atas UU No. 24 Tahun 2004 Tentang LPS. 
(KPMM), mengantisipasi potensi kerugian; dan ayat (2) mengenai tambahan modal.

Pasal 7 ayat (1) ditetapkan mengenai pemenuhan tingkat likuiditas. Pasal 7 (2) pemenuhan tingkat likuiditas sebagaimana dimaksud pada ayat (1) memperhitungkan perkiraan dana masuk minimal selama 6 (enam) bulan dan maksimal selama 1 (satu) tahun sejak bank menjadi Bank gagal dengan memperhatikan kondisi bank.

Menurut Rudy D. Siregar, dalam praktiknya, penanganan bank gagal tidak berdampak sistemik dilakukan dengan penyelesaian, yaitu bank dicabut izin usahanya dan simpanan nasabah dibayarkan melalui LPS, atau dengan penyelamatan, yaitu penyertaan modal sementara. ${ }^{15}$

\section{F. Penutup}

LPS adalah suatu lembaga independen yang berfungsi menjamin simpanan nasabah perbankan di Indonesia. Badan ini dibentuk berdasarkan UU Nomor 24 tentang Lembaga Penjamin Simpanan yang ditetapkan pada 22 September 2004. Undang-undang ini mulai berlaku efektif 12 bulan sejak diundangkan sehingga pendirian dan operasional LPS dimulai pada 22 September 2005. LPS adalah perwujudan dari DPS menggunakan skim perlindungan simpanan yang eksplisit. Setiap bank yang melakukan kegiatan usaha di wilayah Republik Indonesia wajib menjadi peserta penjaminan LPS.

Landasan yuridis berkaitan dengan LPS, antara lain: UURI Nomor 10 Tahun 1998 tentang Perbankan, pada Pasal 37 B yang merupakan Perubahan UURI No. 7 Tahun 1992 mengamanatkan pembentukan suatu LPS sebagai pelaksana penjaminan dana masyarakat; UU Nomor: 3 Tahun 2004 tentang BI pasal 11 ayat 5; UU Nomor 24 Tahun 2004 tentang LPS; UU Nomor 7 Tahun 2009 tentang Penetapan Peraturan Pemerintah Pengganti Undang-Undang Nomor 3 Tahun 2008 tentang Perubahan Atas Undang-Undang Nomor 24 Tahun 2004 tentang LPS Menjadi Undang-Undang; UU No. 21 Tahun 2011 tentang OJK; Perpu No. 3 Tahun 2008 tentang Perubahan Atas UU No. 24 Tahun 2004 Tentang LPS; Peraturan Pemerintah Republik Indonesia Nomor 66 Tahun 2008 tentang Besaran Nilai Simpanan yang Dijamin LPS; Peraturan LPS Republik Indonesia Nomor 3/PLPS/2011 tentang Perubahan Kedua

15 D. Rudy Siregar, LPS dan Kepastian Hukum Penyelamatan Bank gagal, Konsultasihukumjakarta.com, Portal Badan Pendidikan dan Pelatihan Keuangan Menteri Keuangan. 
Atas Peraturan Lembaga Penjamin Simpanan Nomor 4/PLPS/2006 Tentang Penyelesaian Bank gagal yang Tidak Berdampak Sistemik; Keputusan Presiden Nomor 26 Tahun 1998 tentang Jaminan Terhadap Kewajiban Pembayaran Bank Umum; dan Keputusan Presiden Nomor 193 Tahun 1998 tentang Jaminan Terhadap Kewajiban Pembayaran Bank Perkreditan Rakyat.

\section{DAFTAR PUSTAKA}

bi.go.id diakses tanggal 14 Desember 2015.

kemenkeu.go.id diakses tanggal 14 Desember 2015.

Kusumaningtuti S. S. 1998 . Ketentuan Blanket Guarantee dan Kemungkinan Penggantiannya dengan Deposit Protection Scheme. Jakarta: Buletin Ekonomi Moneter dan Perbankan.

lps.go.id diakses tanggal 22 Desember 2015.

Lubis, Samman Abu. 2014. Memahami Peran Lembaga Penjamin Simpanan sebagai Jaring Pengaman Sistem Perbankan Nasional (Makalah).

Perpu Nomor 3 Tahun 2008 tentang Perubahan Atas Undang-Undang Nomor 24 Tahun 2004 tentang Lembaga Penjamin Simpanan

Siregar, Rudy. "LPS dan Kepastian Hukum Penyelamatan Bank gagal". Portal Badan Pendidikan dan Pelatihan Keuangan Menteri Keuangan dalam konsultasihukumjakarta.com.

Undang-Undang Nomor 21 Tahun 2011 tentang Otoritas Jasa Keuangan. Undang-Undang Nomor 24 Tahun 2004 tentang Lembaga Penjamin Simpanan. 